\title{
Magnesium metabolism in growing pigs
}

\section{A. POINTILLART, Michèle ESTABLIER *, Nicole FONTAINE, Colette COLIN}

\author{
I.N.R.A., Station de Recherches de Nutrition, 78350 Jouy-en-Josas \\ * Stagiaire 1981-1982 de l'Ecole nationale supérieure féminine d'Agriculture \\ de Rennes: \\ France
}

This report gives data obtained on $\mathrm{Mg}$ metabolism from several experiments with 130 growing pigs (from 15 to $60 \mathrm{~kg}$ ). Standard (cereals and soyabean meal) and semisynthetic (casein and starch) diets with various levels of calcium, magnesium, phosphorus and vitamin D, were used. The following parameters were measured : absorption, retention, urinary and faecal excretion, plasma and bone $\mathrm{Mg}$ levels. $\mathrm{Mg}-\mathrm{P}$ interaction was also considered. Whatever the diet, the faecal and urinary excretion as well as the absorption and retention of magnesium depended on the dietary $\mathrm{Mg}$ level. A high correlation was found between $\mathrm{Mg}$ intake and all those parameters (from 0.85 to 0.99 ). The lowest correlation appeared between urinary $\mathrm{Mg}$ and $\mathrm{Mg}$ intake because of a high negative interaction between phosphorus/or magnesium intake and urinary magnesium/or phosphorus excretion : the higher the phosphorus ingestion, the lower the urinary magnesium excretion and vice versa. In contrast to other species in which a high antagonism effect is generally observed between $\mathrm{P}$ and $\mathrm{Mg}$ absorption, a positive relationship was found between the absorption of these minerals in pigs. The minimum $\mathrm{Mg}$ requirement was calculated by extrapolation of endogenous $\mathrm{Mg}$ excretion in the faeces (400-700 $\mathrm{mg} /$ day). This can largely be satisfied by usual diets. Plasma levels ranged from 1.6 to $2 \mathrm{mg} / 100 \mathrm{ml}$ (mean $\pm \mathrm{SD}, \mathrm{n}=500$ was $1.83 \pm 0.03$ ) when animals were fed the control diets. Bone $\mathrm{Mg}$ contents ranged from 0.3 to $0.7 \mathrm{p}$. 100 on dry basis, with an overall mean of $0.4 \mathrm{p}$. 100 ; it decreased with age up to 4 months. These two parameters varied with the $\mathrm{Mg}$ intake and thus could not be used as requirement criteria. The apparent digestibility and retention coefficients of magnesium (30 and 20 p. 100 of $\mathrm{Mg}$ intake, respectively) were extremely variable from one experiment to another and were lower than those of $\mathrm{Ca}$ and $\mathrm{P}$ (near $50 \mathrm{p} .100$ ). $\mathrm{Mg}$ deficiency is not importante in practive, but this is not the case for $\mathrm{Mg}$ overload which in addition to diarrhea may lead to bone mineralization disturbances.

\section{PATHOLOGIE \\ PATHOLOGY}

\section{Sow milk : humoral and cellular components involved in protection of young piglets against infectious enteritis}

\author{
S. BERNARD, J.M. AYNAUD, H. SALMON \\ I.N.R.A., Laboratoire de Pathologie porcine, \\ Centre de Recherches de Tours, Nouzilly, B.P. 1, 37380 Monnaie
} France

Sow milk has exeptional immunological qualities as compared with cow or ewe milk. Immunoglobulin concentration is high especially that of the IgA class. The concept of lactogenic immunity was clearly established 18 years ago, and numerous research works about T.G.E., E. coli or rotavirus have described the characteristics of immune protection 
conferred by milk in swine species. Antibodies of the IgA class have a privileged function in the passive protection of piglets against enteritis caused by these enteric agents. The other humoral components (lactoferrin, lysozyme, lactoperoxydase) are still unknown. Recent works have described the different cellular subsets in milk, but their respective roles in the immune protection of young piglets have not been well established. Kinetics of lymphocyte subpopulations and plasma-cells was studied recently in the mammary gland of primiparous sows in relation to pregnancy and lactation. The determinism of the migration of lymphocytes towards the mammary tissue is unknown. Condition of lactogenic immunity seems to depend on several important parameters :

a) the properties of the enteric agent used as an antigen for immunization,

b) the conditions of administration of this antigen to the pregnant sow,

c) the physiological status of the sow at the time of antigen administration.

\title{
Identification of porcine epidemic diarrhoea (P.E.D.) in Brittany A clinical study
}

\author{
P. VANNIER, P. DEBOUCK
}

Ministère de l'Agriculture, Direction de la Qualité, Services vétérinaires, Station de Pathologie porcine, B.P. 9, 22440 Ploufragan

France

*Faculté de Médecine vétérinaire, Laboratoire de Virologie, Casinoplein 24, B 9000 Gand Belgique

Several cases of contagious gastro-enteritis were observed in Brittany during the winter 1981-1982. A study was made in 9 herds in which pigs suffered from digestive disorders. Faeces were collected and antibody kinetics studied in sick animals. No cases of transmissible gastroenteritis were found; contrary to that Porcine Epidemic Diarrhoea (P.E.D.) virus was identified and a seroconversion observed in nearly all the tested sera. A clinical study was performed in these herds. Diarrhoea appeared in unweaned piglets in almost 50 p. 100 of the herds ; the intensity of the observed clinical signs and the piglet mortality rate varied in the different herds according to some parameters which are difficult to evaluate. In all cases, most of the breeding animals and bacon pigs were affected. The mortality conditions of some bacon pigs were discussed.

\section{Porcine influenza in Brittany (Influenza $\mathrm{HSW}_{1} \mathrm{~N}_{1}$ )}

\author{
F. MADEC, J.M. GOURREAU *, C. KAISER *, A. VIGOUROUX **, \\ F. SALINGARDES **, P. PRIME** \\ Ministère de l'Agriculture, Direction de la Qualité, Services' vétérinaires, \\ Station de Pathologie porcine, B.P. 9, Ploufragan \\ * Ministère de l'Agriculture, Direction de la Qualité, \\ Laboratoire central de Recherches vétérinaires, 22, rue Pierre-Curie, B.P. 67, \\ 94703 Maisons-Alfort \\ ** Ministère de l'Agriculture, \\ Direction départementale des Services vétérinaires du Finistère, \\ 7, rue Anne-Robert-Jacques-Turgot, 29107 Quimper \\ France
}

An outbreak of influenza occurred in Brittany (France) in december 1981 and the disease widely spread throughout the country until september 1982. Most of the herds were affected and the clinical signs were similar to those described in other countries. Illness 